\title{
Reproductive phenology, pollination and seed dispersal syndromes on sandstone outcrop vegetation in the "Chapada Diamantina", northeastern Brazil: population and community analyses ${ }^{1}$
}

\author{
ABEL AUGUSTO CONCEIÇÃO ${ }^{2,4}$, LIGIA SILVEIRA FUNCH ${ }^{2}$ and JOSÉ RUBENS PIRANI ${ }^{3}$
}

(received: February 23, 2006; accepted: August 23, 2007)

\begin{abstract}
Reproductive phenology, pollination and seed dispersal syndromes on sandstone outcrop vegetation in the "Chapada Diamantina", northeastern Brazil: population and community analyses). Vegetation on rock outcrops in the "Chapada Diamantina" (soil islands) is often aggregated and surrounded by nude rock surfaces, thus creating natural units with well defined limits. The flowering and fruiting cycles of plants on 58 soil islands at altitudes between 1,100 and 1,140 meters above sea leavel were analyzed at Mãe Inácia Peak (12 $27^{\circ}$ S and 41 ${ }^{\circ} 28^{\prime} \mathrm{W}$ ) in the "Chapada Diamantina", Bahia, Brazil. The presence/ absence of flowering and fruiting species on each soil island, and their respective cover areas were analyzed at both the population and community levels, and the phenophases of flowering and fruiting were observed during 24 successive months. The analyses of pollination and seed dispersal syndromes indicated that animals are more important in pollination than in seed dispersal (which is predominantly by anemochory and autochory). The flowering and fruiting of plants with animal pollination syndromes were correlated with rainfall and temperature. The flowering season varied during the year according to the pollination syndrome involved: entomophily was predominant from summer through autumn, ornithophily was predominant during winter, and anemophily in the spring. The staggered timing of flowering and fruiting among different species provides a nearly continuous supply of resources for the local fauna.
\end{abstract}

Key words - flowering, fruiting, insular sandstone outcrop vegetation, phenology, syndromes

RESUMO - (Fenologia reprodutiva e síndromes de polinização e dispersão de semente em vegetação sobre afloramentos de arenito na Chapada Diamantina, Nordeste do Brasil: análises de população e comunidade). Parte da vegetação sobre afloramentos rochosos na Chapada Diamantina são agregados limitados pela superfície rochosa sem plantas vasculares (ilhas de solo), constituindo unidades naturais com limites bem definidos. Os ciclos de floração e frutificação de 58 ilhas de solo foram

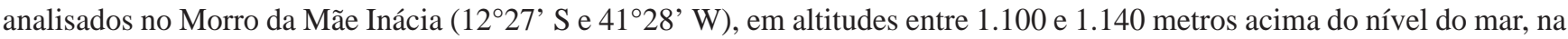
Chapada Diamantina, Bahia, Brasil. As presenças e ausências de espécies com flores e frutos em cada ilha de solo e respectivas áreas de cobertura foram analisadas nos níveis de população e comunidade. As fenofases de floração e frutificação nas ilhas foram realizadas durante 24 observações mensais. As análises das síndromes de polinização e dispersão de sementes indicaram que os animais são mais importantes para polinização do que para dispersão (predominantemente anemocoria e autocoria). A floração e frutificação das plantas que apresentam síndromes de polinização por animais foram correlacionadas com precipitação e temperatura. O período de floração variou de acordo com as síndromes de polinização envolvidas: entomofilia predominou do verão ao outono, ornitofilia predominou durante o inverno e anemofilia durante a primavera. Os períodos intercalados de floração e frutificação das espécies garantem contínuo suprimento de recursos para fauna local.

Palavras-chave - fenologia, floração, frutificação, síndromes, vegetação insular em afloramento de arenito

\section{Introduction}

The phenological characteristics of plants are essential elements in vegetation community dynamics, and they exercise a strong influence on resources

\footnotetext{
1. This work is part of a $\mathrm{PhD}$ thesis developed at the Universidade de São Paulo, Departamento de Botânica, São Paulo, SP, Brazil.

2. Universidade Estadual de Feira de Santana, Departamento de Ciências Biológicas, BR 116, km 03, 44031-460 Feira de Santana, BA, Brazil.

3. Universidade de São Paulo, Instituto de Biociências, Departamento de Botânica, Caixa Postal 11461, 05422-970 São Paulo, SP, Brazil.

4. Corresponding author: abel18@gmail.com
}

available to many organisms. Pollination and dispersal are crucial to plant reproduction, and to their ability to establish new populations on unoccupied sites. It is a critical component of the maintenance of biological diversity (Monasterio \& Sarmiento 1976, Primack \& Miao 1992, Newstrom et al. 1994, Howe \& Westley 1997).

Plant communities on small, well-defined areas on rock outcrops are limited to species that can tolerate (or avoid) severe restrictions of water, nutrients, and soil (Collins et al. 1989, Burrows 1990, Ware 1990). These restrictions are accentuated on mountain tops, where marked oscillations of wind speed and temperature make establishment and growth even more difficult (Steyermark 1986, Safford \& Martinelli 2000). These 
special communities completely surrounded by rock surfaces are called "soil mat communities" in Africa (Hambler 1964), "island communities" in the United States (Burbanck \& Platt 1964, McCormick et al. 1974, Shure \& Ragsdale 1977), and "soil islands" in Brazil (Meirelles 1996).

Some of the highest peaks in northeastern Brazil are found in the Chapada Diamantina Mountain Range. Many endemic species are found in "campo rupestre" vegetation occurring on mountain tops with large areas of exposed rock (Giulietti \& Pirani 1988, Harley 1995, Giulietti et al. 1997, Conceição 2000). These rock outcrop communities are dominated by a restricted group of plants, including species of Velloziaceae (Conceição \& Giulietti 2002, Conceição 2003, Conceição \& Pirani 2005, Conceição et al. 2007) that can survive dehydration during dry periods but quickly re-hydrate with the first rains (Gaff 1977, Meguro et al. 1977, Meirelles et al. 1997).

The only phenological study of soil islands undertaken in Brazil (Meirelles 1996) reported that flowering occurred mainly during the rainy season and that lifeform was an important factor related to the phenological patterns of these plants, especially in the case of geophytes, for which all above-ground parts are absent during the driest months. The studies examining aspects of pollination and floral biology have been undertaken in areas of "campo rupestre" usually focused a low number of species (Sazima 1978a,b, Borba \& Semir 2001, Madeira \& Fernandes 1999, Borba et al. 2001, Carmo \& Franceschinelli 2002). Only a sigle study considered more complex systems, sampling all mellitophilous plants and the Apoidea bees in a 1 ha area of "campo rupestre" (Faria \& Camargo 1996).

The present study sought to detect the patterns of flowering and fruiting in insular plant communities growing on rocky surfaces at "Chapada Diamantina", as well as to relate these patterns to climatic factors (rainfall and temperature) and pollination and seed dispersal syndromes.

\section{Material and methods}

Study site - The soil islands examined are located on sandstone outcrops at altitudes between 1,100 and $1,140 \mathrm{~m}$ a.s.l. at the Mãe Inácia Peak ( $12^{\circ} 27^{\prime} \mathrm{S}$ and $\left.41^{\circ} 28^{\prime} \mathrm{W}\right)$, in the municipality of Palmeiras, "Chapada Diamantina", Bahia, Brazil.

The climate in the region of the Mãe Inácia Peak is classified as Central Brazil Tropical (Nimer 1989), with a humid summer season and four to five months of drought. Maximum rainfall is from December to April, while July and August are the coldest months, having frequent morning fogs (Jesus et al. 1983). The mean annual temperatures in areas between 1,000 and $1,100 \mathrm{~m}$ a.s.l. are less than $20^{\circ} \mathrm{C}$, with the possibility of daily minimums below $4{ }^{\circ} \mathrm{C}$ (Nimer 1989). Daily temperature amplitudes vary on average from 8 to $10{ }^{\circ} \mathrm{C}$ during the day, with the largest amplitudes occurring at the highest altitudes (Jesus et al. 1983). During the study period (2000 to 2002), there were four months with less than $20 \mathrm{~mm}$ of rainfall, while the months of February and November had the warmest average temperatures (figure 1C).

The "campo rupestre" vegetation growing on Mãe Inácia Peak is composed of a mosaic of distinct communities distributed heterogeneously across the landscape according to the type of substrate. The vegetation on the rocky surfaces at the very top of the mountain is composed of herbaceous plants, shrubs, and small trees, and is dominated by Velloziaceae, Clusiaceae, Cyperaceae, Orchidaceae, and Melastomataceae. The first family is responsible for approximately $44 \%$ of the total vegetation cover (Conceição \& Pirani 2005).

Soil islands are insular units composed of two or more species of vascular plants sharing the same patch of soil that is otherwise surrounded by a bare rock surface devoid of any vascular plants (Conceição \& Pirani 2005). The study area was selected based on its high proportion of rock surfaces, as well as its accessibility and reduced human interference. Two plots were established: a $100 \times 320 \mathrm{~m}$ rectangle $(32,000$ $\left.\mathrm{m}^{2}\right)$, and a $100 \times 100 \mathrm{~m}$ square $\left(10,000 \mathrm{~m}^{2}\right)$, each of then divided into 10 x $10 \mathrm{~m}$ square sub-plots. Six sub-plots were chosen by lottery, and all of the soil islands entirely or partially included within these six areas were identified and numbered, yielding a total of 58 individual soil islands.

The ground coverage of the different plant species composing each island were visually estimated based on the vertical projection of all aerial plants parts. The surface areas of the islands themselves were estimated by measuring their longest axis (l) and greatest width (w), then, based on the general form of the island, either the area of an ellipse ( $1 / 41 . w . p)$ or a rectangle (l.w) was calculated. Voucher specimens of all species studied are housed at the herbarium SPF ("Universidade de São Paulo").

Phenology - The presence or absence of plants with flowers or fruits in each of the 58 soil islands studied was recorded on a monthly basis from November 2000 to October 2002, generating a binary matrix of their phenophases. Due to the difficulty in distinguishing single individuals, especially among monocot species, clumps of each species were examined. The same species in the 58 islands were treated as a population, and all the species in the 58 islands together were treated as a single community.

Flowering was defined as including all phases from budding to anthesis; fruiting was defined as including all phases from the immature fruit through seed dispersal. Phenological patterns were analyzed and classified according to Newstrom et al. (1994). Pollination syndromes were classified as those mediated by bats (chiropterophily), birds (ornithophily), insects (entomophily), or wind (anemophily) (Faegri \& van der Pijl 1979). The diaspores were classified according to their dispersal by wind (anemochory), animals (zoochory), or self-dispersal (autochory). These syndromes 
were determined based on fruit type, mesocarp, colour and diaspore size (van der Pijl 1982). Spearman's rank correlation coefficients were used to evaluate the relationship between the climatic factors (temperature and rainfall) recorded during the 24 mouths of study and the presence of flowers and fruits on soil islands, as well as to the area covered by each flowering and fruiting species. The analyses were performed to total number of soil islands for which flowers or fruits were recorded, as well as to total number of soil islands for which flowers or fruits of each pollination and seed dispersal syndromes were recorded. The total rainfall on the day of the data collection, as well as during the six day period immediately preceding it, was considered weekly rainfall. Calculations were performed using the Statistica 6.0 software program.

\section{Results}

General aspects - Table 1 lists the 43 species of angiosperms encountered in the 58 soil islands examined, their pollination and seed dispersal syndromes, as well as the total number of soil islands for which flowers or fruits were recorded for each species. Of the 43 species examined, 22 were eudicotyledons and 21 were monocotyledons. Eudicotyledons were represented by
13 families, with Asteraceae presenting the greatest number of species (four). Monocotyledons were concentrated in nine families of which Orchidaceae (six species) and Velloziaceae (four) were the most species rich. Of the total number of species, $42 \%$ (18) did not flower or fruit during the survey period. These were generally species occurring in low numbers or represented by immature individuals only. There were seven species with more than 50 recorded flowers or fruits: Acianthera (Pleurothallis) ochreata (797 total), Barbacenia blanchetii (545), Vellozia hemisphaerica (321), Trilepis lhotzkiana (240), Clusia obdeltifolia (79), Tibouchina pereirae (68), and Spigelia cremnophila (62). The presence of flowers and fruits among these species were responsible for more than $90 \%$ of the total number of flowers and fruits observed in the 58 soil islands sampled. Patterns at the community level - The majority $(63 \%)$ of the vegetation cover of the 58 soil islands was comprised by 27 entomophilous species plants. Seven ornithophilous species represented $29 \%$ of the coverage. Seven anemophilous species were responsible for $6 \%$ of the total cover, while two chiropterophilous species were responsible for the remaining $2 \%$.

Table 1. Species of angiosperms occurring on 58 soil islands at the Mãe Inácia Peak, "Chapada Diamantina”, Bahia, Brazil. Pol = pollination syndromes: ane $=$ anemophily, ento $=$ entomophily, orni $=$ ornithophily, $\mathrm{ch}=$ chiropterophily. $\mathrm{Di}=$ seed dispersal syndromes: $\mathrm{an}=$ anemochory, $\mathrm{zo}=$ zoochory, au = autochory. $\mathrm{Fl}$ and $\mathrm{Fr}=$ number of soil islands $(n=58)$ for which flowers $(\mathrm{Fl})$ and fruits (Fr) were recorded during the 24 monthly observations.

\begin{tabular}{|c|c|c|c|c|c|}
\hline Species & Material voucher & Pol & Di & $\mathrm{Fl}$ & Fr \\
\hline \multicolumn{6}{|l|}{ EUDICOTYLEDONS } \\
\hline \multicolumn{6}{|l|}{ Apocynaceae } \\
\hline Mandevilla bahiensis (Woodson) M. F. Sales & Conceição 219 & ento & an & - & - \\
\hline Mandevilla tenuifolia (Mikan) Woodson & Conceição 208 & ento & an & - & - \\
\hline \multicolumn{6}{|l|}{ Asteraceae } \\
\hline Acritopappus morii R. M. King \& H. Rob. & Grillo 70 & ento & an & - & - \\
\hline Bahianthus viscosus (Spreng.) R. M. King \& H. Rob. & Conceição 56 & ento & an & 5 & 6 \\
\hline Lasiolaena duartei R. M. King \& H. Rob. & Conceição 133, 608 & ento & an & - & - \\
\hline Lychnophora triflora (Mattf.) H. Rob. & Conceição 55, 1051 & ento & an & 3 & 19 \\
\hline \multicolumn{6}{|l|}{ Begoniaceae } \\
\hline Begonia grisea A. DC. & Conceição 205 & ento & an & 1 & - \\
\hline \multicolumn{6}{|l|}{ Cactaceae } \\
\hline Micranthocereus purpureus (Gürke) F. Ritter & Zappi 141 & orni & zo & - & 2 \\
\hline Pilosocereus pachycladus F. Ritter & Harley 25562 & ch/ento & zo & - & - \\
\hline \multicolumn{6}{|l|}{ Clusiaceae } \\
\hline Clusia obdeltifolia Bittrich & Conceição 287 & ento & zo & 50 & 29 \\
\hline \multicolumn{6}{|l|}{ Convolvulaceae } \\
\hline Evolvulus jacobinus Moric. & Conceição 303 & ento & $\mathrm{au}$ & - & - \\
\hline \multicolumn{6}{|l|}{ Lamiaceae } \\
\hline Eriope exaltata Harley & Conceição 36 & orni & $\mathrm{au}$ & 7 & 7 \\
\hline
\end{tabular}


continuation

\begin{tabular}{|c|c|c|c|c|c|}
\hline Species & Material voucher & Pol & Di & $\mathrm{Fl}$ & $\mathrm{Fr}$ \\
\hline \multicolumn{6}{|l|}{ Loganiaceae } \\
\hline Spigelia cremnophila Zappi \& E. Lucas & Conceição 64 & ento & $\mathrm{au}$ & 32 & 30 \\
\hline \multicolumn{6}{|l|}{ Melastomataceae } \\
\hline Marcetia vellutina Markgr. & Conceição 142 & ento & an & 1 & 12 \\
\hline Tibouchina pereirae Brade \& Markgr. & Grillo 32 & ento & an & 21 & 47 \\
\hline \multicolumn{6}{|l|}{ Myrtaceae } \\
\hline Myrcia myrtifolia DC. & Conceição 295, 730 & ento & zo & - & - \\
\hline \multicolumn{6}{|l|}{ Polygalaceae } \\
\hline Polygala guedesiana Marques & Conceição 857 & ento & zo & 5 & - \\
\hline \multicolumn{6}{|l|}{ Rubiaceae } \\
\hline Declieuxia aspalathoides Müll. Arg. & Grillo 25 & ento & $\mathrm{au}$ & - & - \\
\hline Hillia parasitica Jacq. & Conceição 358 & ento & an & - & - \\
\hline \multicolumn{6}{|l|}{ Verbenaceae } \\
\hline Stachytarpheta crassifolia Schrad. & Conceição 31 & orni & $\mathrm{au}$ & 11 & 18 \\
\hline Stachytarpheta froesii Moldenke & Conceição 1050 & orni & $\mathrm{au}$ & 19 & 17 \\
\hline \multicolumn{6}{|l|}{ MONOCOTYLEDONS } \\
\hline \multicolumn{6}{|l|}{ Amaryllidaceae } \\
\hline Hippeastrum puniceum (Lam.) Kuntze & V.C.Souza 5226 & ento & an & - & - \\
\hline \multicolumn{6}{|l|}{ Araceae } \\
\hline Philodendron pachyphyllum Krause & Conceição 402 & ento & zo & - & - \\
\hline \multicolumn{6}{|l|}{ Bromeliaceae } \\
\hline Hohenbergia cf. catingae Ule & Conceição 407 & orni & zo & - & - \\
\hline Tillandsia $\mathrm{sp}$. & orni & an & - & - & \\
\hline Vriesea atra $\mathrm{Mez}$ & Conceição 408 & ch/ento & an & - & - \\
\hline \multicolumn{6}{|l|}{ MONOCOTYLEDONS } \\
\hline \multicolumn{6}{|l|}{ Cyperaceae } \\
\hline Abildgaardia sp. & Conceição 560 & ane & an & 4 & 19 \\
\hline Bulbostylis aff. jacobinae (Steud.) Lindm. & Conceição 984 & ane & an & - & 4 \\
\hline Trilepis lhotzkiana Nees & Conceição 308 e 448 & ane & an & 41 & 199 \\
\hline \multicolumn{6}{|l|}{ Dioscoreaceae } \\
\hline Dioscorea sincorensis $\mathrm{R}$. Knuth & Conceição 293 e 435 & ento & an & - & - \\
\hline \multicolumn{6}{|l|}{ Eriocaulaceae } \\
\hline Leiothrix angustifolia (Körn.) Ruhland & Conceição 635 & ento & an & 1 & 1 \\
\hline \multicolumn{6}{|l|}{ Orchidaceae } \\
\hline Cattleya elongata Barb. Rodr. & PCD 1741 & ento & an & 8 & 10 \\
\hline Cyrtopodium edmundoi Pabst & PCD 1136 & ento & an & - & - \\
\hline Habenaria entomantha (Lallave \& Lex.) Lindl. & Conceição 1053 & ento & an & 1 & - \\
\hline Acianthera ochreata (Lindl.) Pridgeon \& M. W. Chase & Conceição 70 & ento & an & 480 & 317 \\
\hline Prescottia plantagines Lindl. & Conceição 894 & ento & an & - & - \\
\hline Sacoila lanceolata (Aubl.) Garay & Conceição 755, 977 & ento & an & 2 & 1 \\
\hline \multicolumn{6}{|l|}{ Poaceae } \\
\hline Schizachyrium sanguineum (Retz.) Alst. & Conceição 576 & ane & an & 8 & 4 \\
\hline Trachypogon macroglossus Trin. & Conceição 915 & ane & an & - & - \\
\hline \multicolumn{6}{|l|}{ Velloziaceae } \\
\hline Barbacenia blanchetii Goethart \& Henrard & Conceição 49 & orni & $\mathrm{au}$ & 409 & 136 \\
\hline Barbacenia sp. & Conceição 511 & ento & $\mathrm{au}$ & 1 & - \\
\hline Vellozia dasypus Seub. & Conceição 909 & ento & $\mathrm{au}$ & 1 & 12 \\
\hline Vellozia hemisphaerica Seub. & Conceição 113 & ento & $\mathrm{au}$ & 30 & 291 \\
\hline Total & & & & 1141 & 1181 \\
\hline
\end{tabular}


The total number of flowers observed during the first year was only slightly greater than that observed during the second year, although flowering tended to be continuous in 2001 and annual in 2002 (figure 1A). The anemophilous species had an annual, regular, and intermediate pattern of flowering, with greatest activity in the middle of the dry season (September - December).

Entomophilous species predominated on soil islands, also demonstrating an annual, regular and intermediate pattern of flowering, though having their greatest activity during the period between December and May. Pink and purple flowers dominated among this group. Red flowers predominated among ornithophilous species, wich accompanied the general tendency of the community as a whole, with greatest flowering activity occurring from December 2001 to May 2002. A minor flowering was observed during the driest months (figure 1A).

Seed dispersal in the soil islands occurred predominantly by autochory ( 10 species, $56 \%$ of the vegetation cover) and anemochory (26 species, $23 \%$ of the vegetation cover), while $21 \%$ of the remaining cover was occupied by seven zoochoric species.

Fruit production in soil islands was continuous, with almost twice the total number of occurrences of fruits in the second year (2002) than in the first (figure 1B). Autochory dominated (in vegetation cover) during most of the months, indicating the importance of this syndrome in community fruit production. Anemochoric species also presented a continuous pattern of fruiting. Zoochoric species were infrequent, but showed annual, irregular, and intermediate fruiting. The period of greatest fruit production of zoochoric species was in the rainy season.

Flowering was correlated with total number of species with flowers and weekly rainfall $\left(r_{s}=0.41 ; P<0.05\right)$, and species with entomophilous flowers correlated with monthly temperatures $\left(r_{s}=0.48 ; P<0.05\right)$. Spearman correlations were significant in terms of the area of total cover of species with flowers and weekly rainfall $\left(r_{s}=\right.$ $0.52 ; P<0.05)$; the area of total cover of species with ornithophilous flowers and weekly rainfall $\left(r_{s}=0.44 ; P\right.$ $<0.05)$, and the total vegetation cover of species with entomophilous flowers and monthly temperatures $\left(r_{s}=\right.$ $0.47 ; P<0.05)$.

Patterns at the population level - Figure 2 illustrate the phenophases of the seven species demonstrating the largest number of flowers and fruits during the study period. This data represents the number of soils islands with species that flowered or produced fruits divided by the total number of islands on which these same species occurred $(N)$.

The flowering and fruiting patterns of Clusia obdeltifolia were annual, irregular, and intermediate, with an increase in flowering during the wettest months. The flowering and fruiting of Spigelia cremnophila was continuous, ocurring in almost all observations. Tibouchina pereirae had an annual, regular, and intermediate pattern. Flowering of the orchid Acianthera ochreata was annual, regular, and long. Fruiting was also annual, irregular, and long, with the greatest fruit production in 2002. Barbacenia blanchetii demonstrated continuous flowering in 2001 and annual flowering in 2002. The two periods with the lowest number of flowers corresponded to two of the four driest months. Fruit production was sub-annual, irregular, and long. Flowering of Vellozia hemisphaerica was annual and intermediate being especially abundant after heavy rains. Fruiting for this species was annual and long. Flowering of Trilepis lhotzkiana was annual, regular, and intermediate; fruiting was continuous.

The remaining species demonstrated little or no flowering or fruiting, with a generally annual pattern at the population level (except for Stachytarpheta froesii, which was continuous), but a continuous pattern at the community level.

\section{Discussion}

Patterns at the community level - The absence of flowers or fruits among 18 species (42\%) during the two study years may indicate low levels of sexual reproduction among these species, stressing the importance of vegetative reproduction on rock outcrops (Biedinger et al. 2000). However, the study period was too short to fully confirm this assumption. Additionally, most of these species occur on just a few islands and/or they may not have reached a reproductive state.

Although autochory is the predominant seed dispersal syndrome on these islands ( $56 \%$ of their area), anemochory occurs in a large number of species, demonstrating the importance of both dispersal syndromes for insular communities, already noted for an "inselberg" in the state of São Paulo, Brazil (Meirelles 1996). Autochory may confer an advantage in the occupation of soil islands surrounded by exposed rock and thus difficult to colonize. Mathias et al. (2001) suggested that a reduction in the dispersal distance for plant species occupying a favorable habitat in a heterogeneous landscape might have an adaptive advantage, in that it would reduce the possibility of a diaspore being dispersed into a less favorable habitat.

Anemochory provides a vehicle for the expansion of the distribution of a species (Hensen \& Müller 1997), and represents an important vector for the migration of species to soil islands from similarly isolated habitats (Meirelles 1996). Among the seven species with the 

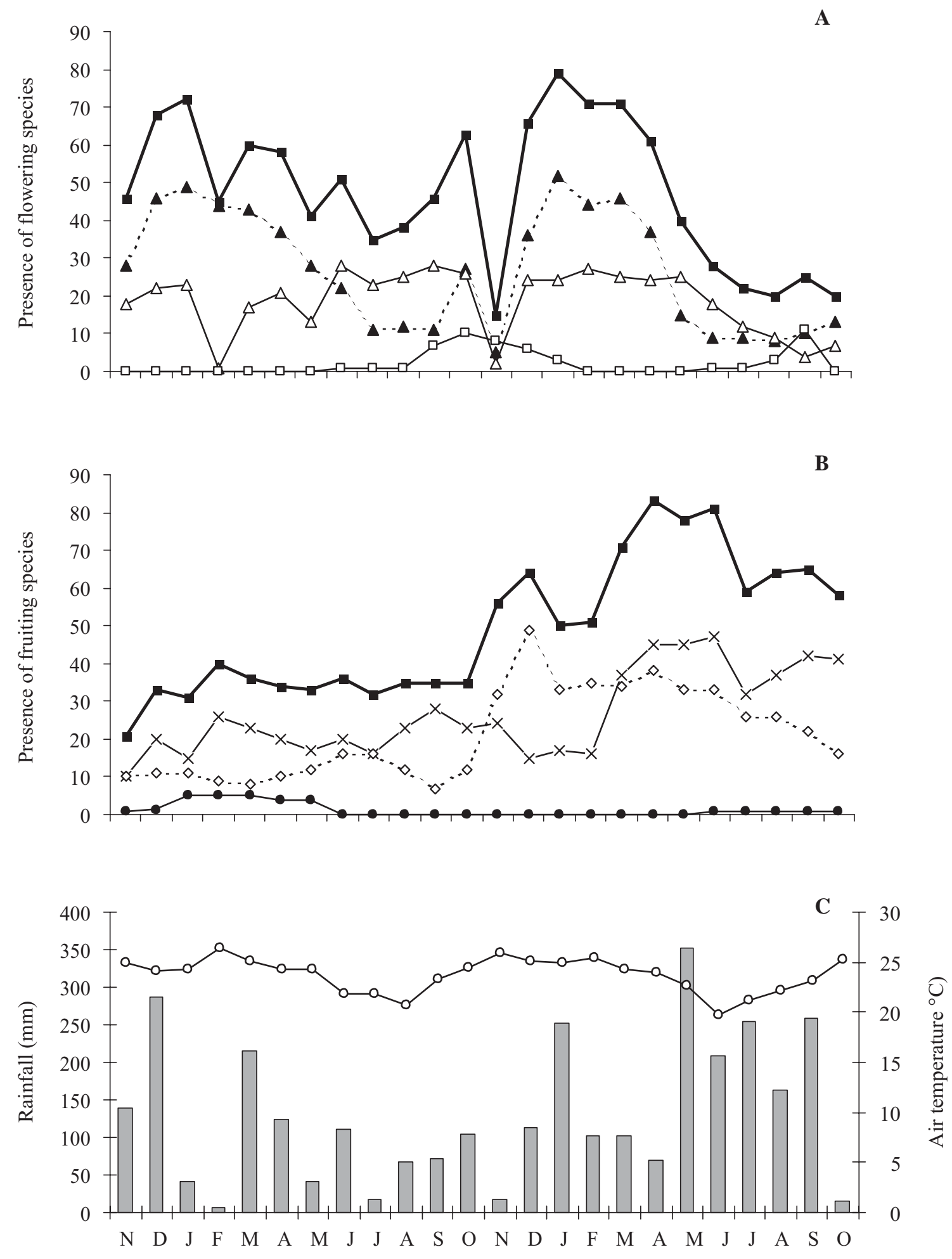

Months

Figure 1. The presence of plant species with flowers (A) and fruits (B) indicating each pollination and seed dispersal syndromes. Total flowers $(623+518:-\square)$; entomophily $(358+284:--\mathbf{\Delta -})$; ornithophily $\left(245+201:--\Delta_{--}\right)$; anemophily $(20+33$ : $-\square-)$. Total fruits $(401+780:--)$; anemochory $(241+398:-x-)$; autochory $(134+377:--0--)$; zoochory $(26+5:--\bullet--)$. The numbers indicated between parentheses refer to the total number of presence of flowers and fruits during the first and second 12-month periods of investigation at the Mãe Inácia Peak. Observations were performed from November 2000 to October 2002. C. Total rainfall (gray bars) and average monthly temperatures (source: INMET, Lençóis), "Chapada Diamantina”, Bahia, Brazil. 
greatest production of flowers and fruits, the anemochoric species (for example Trilepis lhotzkiana and Acianthera ochreata) have the widest geographic range (Meirelles et al. 1997, Borba \& Semir 2001) while the autochoric (Vellozia hemisphaerica and Barbacenia blanchetii, $52.4 \%$ of the total vegetation cover) and zoochoric species (Clusia obdeltifolia, $18.95 \%$ of the total vegetation cover) are endemic to the "Chapada Diamantina" (Conceição 2000), and show high abundance on restricted sites. In spite of the reduced number of zoochoric species (seven), the area occupied by these species is quite significant when compared to the 26 anemochoric species. Zoochory would also confer an advantage in insular habitats by increasing the probability of a seed being dispersed to favorable habitats as animals on rock outcrops tend to seek high-quality habitats (Goldsbrough et al. 2002).

The positive correlation between the presence of flowers and rainfall during the previous week indicates that these plants flower directly in accordance with the quantity of rainfall received immediately beforehand. The production of ornithophilous flowers is also correlated with rainfall during the previous week as is seen, for example, with the heavy flowering of B. blanchetii immediately after intense rain showers. Rainfall was correlated with therophyte growth and high vegetation diversity on rock outcrops in Africa (Porembski \& Barthlott 1997). The increased production of entomophilous flowers after warm spells may be related to the more favorable climate for bee activity (Cruden 1972), as soil islands are found on mountain tops where the wind and cold are often intense, principally during winter (Safford \& Martinelli 2000).

The predominance of entomophilous flowers, followed by ornithophilous and then anemophilous species, as seen in the present work, was also reported for soil islands on inselbergs in southeastern Brazil (Meirelles 1996, Porembski et al. 1998, Safford \& Martinelli 2000) and may indicate a common pattern among exposed insular rock communities. At the Mãe Inácia Peak, entomophilous flowers showing annual flowering offer rewards to a large number and variety of insects, mainly during the rainy season (usually January to May). The insect group Apoideae constitutes one of the most important pollination vectors for the plant family Asteraceae in "campo rupestre" vegetation in the "Serra do Cipó", Minas Gerais State (Faria \& Camargo 1996).

Anemophilous flowers predominated during the month with the lowest precipitation rate at the "Mãe Inácia" site (figure 1A). The elevated incidence of wind pollinated species on some oceanic islands suggests an advantage for anemophily (does not require animal vectors and possibility of genetic flow to long distances) in these remote and restricted habitats for animals (Carlquist 1974, Barrett 1996), and the same may be true for mainland mountain habitats (Meirelles 1996, Porembski et al. 1998, Safford \& Martinelli 2000).

Ornithophilous flowers at the "Mãe Inácia" site offer rewards almost all year round, principally for the hummingbird Augaster lumachellus, endemic to the "campo rupestre" vegetation of the "Chapada Diamantina". This bird is commonly seen visiting flowers of Barbacenia blanchetii and Stachytarpheta froesii. An increase in the proportion of ornithophilous species was observed with increasing altitude in the "campo rupestre" vegetation in the "Serra do Cipó" (Sazima 1978a) as well as in mountain vegetation in Mexico (Cruden 1972). This suggests a greater importance of pollination by hummingbirds at higher altitudes, as is the case at the Mãe Inácia Peak, principally for $B$. blanchetii, a desiccation-tolerant plant with high cover density (Conceição 2003).

The predominance of anemochory for most of the year demonstrates the importance of this seed dispersal mechanism that utilizes the force and frequency of the mountain top winds (figure 1B). By contrast, zoochory predominates in forests, followed by anemochory and autochory (Funch et al. 2002). Zoochory is poorly represented (in terms of either coverage or frequency) at the "Mae Inácia" mountain site, which is consistent with the observation that there are fewer bird species in these mountains than in forest sites (Parrini et al. 1999). It should be remembered that the few resident bird species on the Mãe Inácia Peak also utilize fruits from neighboring habitats (that have taller and more dense vegetation) including those produced by species of Myrtaceae, Leandra, Ilex, and Lantana (Conceição $\&$ Pirani 2005). In open-herbaceous vegetation on sandstone formations in Colombia, autochory was the most important seed dispersal mechanism while zoochory was more important in the low forest-shrub vegetation (Arbeláez \& Parrado-Rosselli 2005).

Patterns at the population level - The patterns of fruiting and flowering of the plant populations analyzed were all continuous and annual, with the single exception of subannual fruiting observed in Barbacenia blanchetii (figure 2). This coincided with the expected organization of individual patterns at the population level (Newstrom et al. 1994). All monocotyledon species in figure 2 showed phenophase(s) with more than $80 \%$ of flowering and/or fruiting, stressing the importance of monocotyledons in the harsh environments of rock outcrops (Meirelles 1996, Porembski et al. 1998, Ribeiro \& Medina 2002, Conceição 


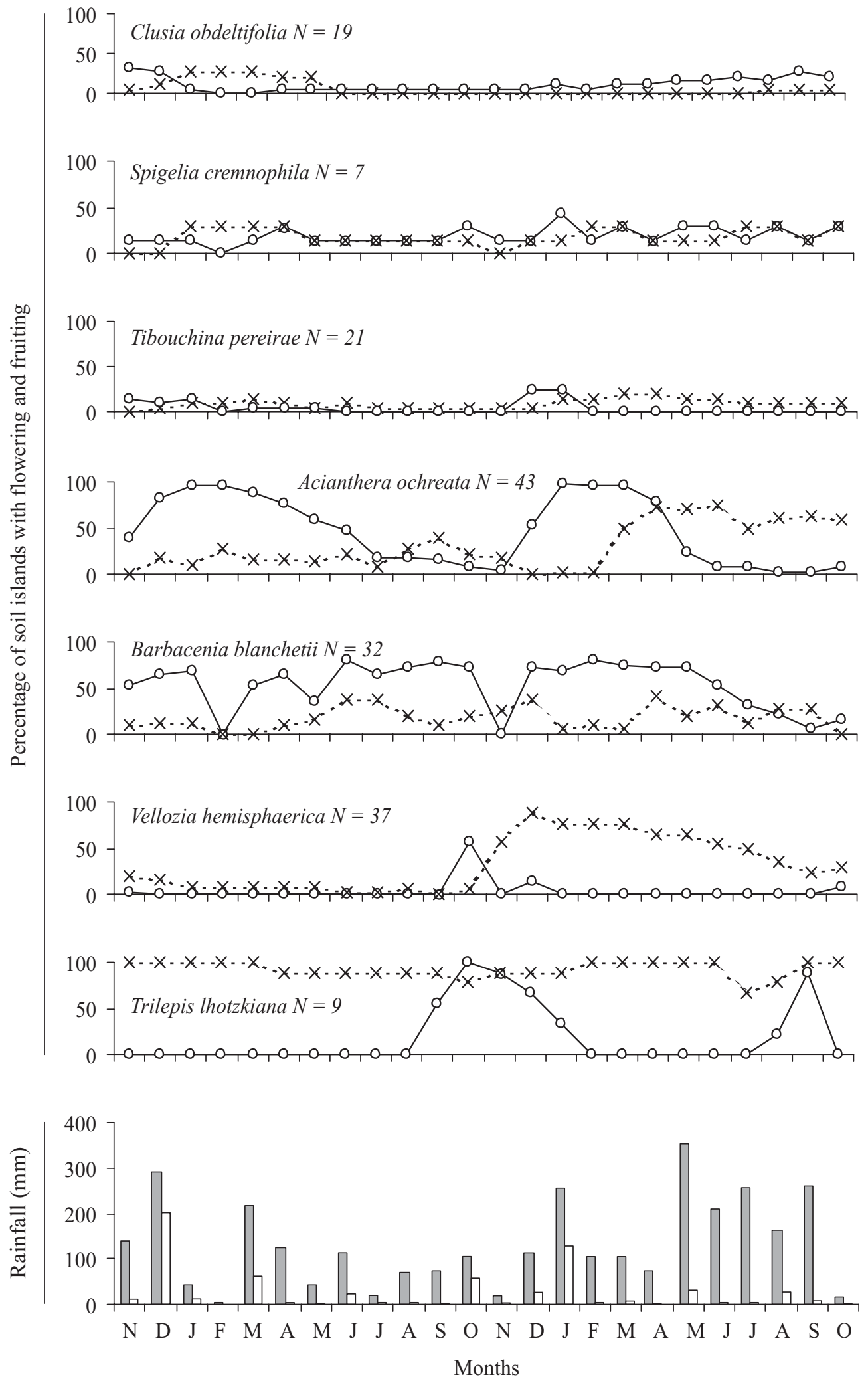

Figure 2. Percentage of presence of species in the phenophases of flowering (-o-) and fruiting (-- $\left.\mathbf{x}^{--}\right)$. This data represents the number of soils islands with species that flowered or produced fruits divided by the total number of islands on which these species occurred $(N)$. The monthly rainfall is the total of rainfall in months (gray bars) and weekly rainfall is the total of rainfall in the day and more six days before of collection data (white bars). Observations were performed from November 2000 to October 2002. "Chapada Diamantina”, Bahia, Brazil. 
2003, Medina et al. 2006, Conceição et al. 2007). The eudicotyledons always showed lower than $50 \%$ of flowering and/or fruiting (Clusia obdeltifolia, Spigelia cremnophila and Tibouchina pereirae - figure 2). This lower flower and/or fruit production would seem to be related to their long flowering and fruiting periods (Bronstein 1995).

Clusia obdeltifolia is unique (figure 2) in having both its pollination and seed dispersal syndromes mediated by animals. This species produced almost no flowers during the driest months of the study period. Fruits were not observed after the flowering period of July 2001 to June 2002, as almost exclusively masculine flowers were produced during that time. Carmo and Franceschinelli (2002) observed that another species of Clusia from an area of "campo rupestre" vegetation also demonstrated greater flower production during the rainy season, with male flowers predominating during drier periods. This low production of masculine flowers can be viewed as offering rewards to pollinators in stressful periods without risking the initiation of fruiting during an unfavorable season. The fruits produced by $C$. obdeltifolia provide food for birds. The high proportion of dioecious plants found on oceanic islands has been associated with seed dispersal by birds (Whittaker 1998). Among five sites studied in "Chapada Diamantina", C. obdeltifolia occurred in four (Conceição \& Giulietti 2002, Conceição \& Pirani 2007), demonstrating the large amplitude of its range. The decrease in flowering of Tibouchina pereirae and Spigelia cremnophila appears to be related to dry periods, and flower production re-initiates when the rainfall returns.

The lack of sufficient water resources for part of the year 2001 apparently inhibited flower production in Acianthera ochreata. On the other hand, the high fruit production observed with this species during 2002 appears to be related to the abundant rainfall that year. Other studies with $A$. ochreata have demonstrated a strong relationship between rainfall and frequency of visitation by flies of the families Phoridae and Chloropidae (Diptera) that are necessary for pollination and fruit formation (Borba \& Semir 2001, Borba et al. 2001).

The decrease in flowering of $B$. blanchetii appears to be closely related to the occurrence of dry spells, as a close association was observed between flowering and the irregular rainfall patterns during the study years. The overall sub-annual fruiting pattern observed for this species would therefore also be related to the marked seasonality of the rainfall. Dry periods may impact flowering and fruiting directly, or may influence the abundance of pollinators or seed dispersal agents (Howe \& Westley 1997, Madeira \& Fernandes 1999, Borba et al. 2001). The other two desiccation tolerant species (Vellozia hemisphaerica and Trilepis lhotzkiana) showed annual and regular flowering, although all three species demonstrated seasonal vegetative patterns (Conceição 2003). T. lhotzkiana does not require animal vectors to complete its life-cycle (anemophily and anemochory), giving it an apparent advantage in establishing new populations in previously unoccupied sites that have few or no animals. The desiccation tolerance of this species also capacitates it as a pioneer perennial plant in harsh rocky environments (Meirelles et al. 1997).

Final considerations - The examination of phenological patterns in tropical regions has demonstrated their complexity, and the importance of distinguishing the level under consideration (individual, population, community) (Newstrom et al. 1994). The distinct differences between pollination and seed dispersal syndromes (based on frequency and cover at the community level) demonstrated a greater importance of animals for pollination (with a predominance of entomophily and ornithophily) than for seed dispersal (which is mainly by anemochory and autochory). The overall pattern of continuous flowering and fruiting at the community level is the result of the sum of the activities of distinct guilds that have overlapping cycles of pollination and seed dispersal (figure 1A, B).

Pollination dependent on biotic agents tends to be continuous, while wind pollination tends to be annual. Dispersal of seeds spread by abiotic agents was continuous, while dispersal of zoochoric seeds demonstrates an annual pattern. These results demonstrate that pollination is greatly dependent on the presence of animals and the quantity of rainfall, while seed dispersal, being mostly abiotic, is prevalent during dry periods. Overlapping periods of flowering and fruiting provide a continuous supply of resources to the local fauna, although the quantity of rainfall and temperature influences both activities, with the wettest seasons being most favorable to the reproduction of plants that are pollinated and/ or dispersed by animals.

Acknowledgements - The authors would like to thank J.A.N. Conceição, R. Funch, and anonymous reviewers for their comments, which have considerably improved the paper; IBAMA for research license; and Fapesp (99/05322-7) for the doctor fellowship and logistic support for A.A. Conceição.

\section{References}

ARBELÁEZ, M.V. \& PARRADO-ROSSELLI, A. 2005. Seed dispersal modes of the sandstone plateau vegetation of the middle Caquetá river region, Colombian Amazonia. Biotropica 37:64-72. 
BARRETT, S.C.H. 1996. The reproductive biology and genetics of island plants. Philosophical Transactions of the Royal Society of London. Series B, Biological Sciences 351:725-733.

BIEDINGER, N., POREMBSKI, S. \& BARTHLOTT, W. 2000. Vascular plants on inselbergs: vegetative and reproductive strategies. In Inselbergs (S. Porembski \& W. Barthlott, eds.). Ecological Studies, v.146. Springer-Verlag, Berlin, p.117-142.

BORBA, E.L. \& SEMIR, J. 2001. Pollinator specificity and convergence in fly-pollinated Pleurothallis (Orchidaceae) species: a multiple population approach. Annals of Botany 88:75-88.

BORBA, E.L., SEMIR, J. \& SHEPHERD, G.J. 2001. Selfincompatibility, inbreeding depression and crossing potential in five Brasilian Pleurothallis (Orchidaceae) species. Annals of Botany 88:89-99.

BRONSTEIN, J.L. 1995. The plant-pollinator landscape. In Mosaic landscapes and ecological processes (L. Hansson, L. Fahrig \& G. Merrian, eds.). Studies in Landscape Ecology v.2. Chapman \& Hall, London, p. 256-288.

BURBANCK, M.P. \& PLATT, R.B. 1964. Granite outcrop comunities of the Piedmont Plateau in Georgia. Ecology 45:292-306.

BURROWS, C.J. 1990. Processes of vegetation change. Urwin Hyman, London.

CARLQUIST, S. 1974. Island biology. Columbia University Press, New York.

CARMO, R.M. \& FRANCESCHINELLI, E.V. 2002. Polinização e biologia floral de Clusia arrudae Planchon and Triana (Clusiaceae) na Serra da Calçada, Município de Brumadinho, MG. Revista Brasileira de Botânica 25:351-360.

COLLINS, S.L., MITCHELL, G.S. \& KLAHR, S.C. 1989. Vegetation-environment relationships in a rock outcrop community in southern Oklahoma. American Midland Naturalist 122:339-348.

CONCEIÇÃO, A.A. 2000. Alerta para a conservação da biota na Chapada Diamantina. Revista Ciência Hoje 27: 54-56.

CONCEIÇÃO, A.A. 2003. Ecologia da vegetação em afloramentos rochosos na Chapada Diamantina, Bahia, Brasil. Tese de doutorado, Universidade de São Paulo, São Paulo.

CONCEIÇÃO, A.A. \& GIULIETTI, A.M. 2002. Composição florística e aspectos estruturais de campo rupestre em dois platôs do Morro do Pai Inácio, Chapada Diamantina, Bahia, Brasil. Hoehnea 29:37-48.

CONCEIÇÃO, A.A. \& PIRANI, J.R. 2005. Delimitação de habitats em campos rupestres na Chapada Diamantina: substratos, composição florística e aspectos estruturais. Boletim de Botânica da Universidade de São Paulo 23: 85-111.

CONCEIÇÃO, A.A. \& PIRANI, J.R. 2007. Diversidade em quatro áreas de campos rupestres na Chapada Diamantina, Bahia, Brasil: espécies distintas, mas riquezas similares. Rodriguésia 58:193-206.
CONCEIÇÃO, A.A., GIULIETTI, A.M. \& MEIRELLES, S.T. 2007. Ilhas de vegetação em afloramentos de quartzitoarenito no Morro do Pai Inácio, Chapada Diamantina, Bahia, Brasil. Acta Botanica Brasilica 21:335-347.

CRUDEN, R.W. 1972. Pollinators in high elevation ecosystems: relative effectiveness of bird and bees. Science 176:14391446.

FAEGRI, K. \& VANDER PIJL,L. 1979. The principles of pollination ecology. Pergamon Press, Oxford.

FARIA, G.M. \& CAMARGO, J.M.F. 1996. A flora melitófila e a fauna de Apoidea de um ecossistema de campos rupestres, Serra do Cipó, MG, Brasil. In Anais do II encontro sobre abelhas de Ribeirão Preto, Universidade de São Paulo, São Paulo, p.217-228.

FUNCH, L.S., FUNCH, R. \& BARROSO, G.M. 2002. Phenology of gallery and montane forest in the Chapada Diamantina, Bahia, Brazil. Biotropica 34:40-50.

GAFF, D.F. 1977. Desiccation tolerant vascular plants of Southern Africa. Oecologia 31:95-109.

GIULIETTI, A.M. \& PIRANI, J.R. 1988. Paterns of geographic distribution of some plant species from the Espinhaço Range, Minas Gerais and Bahia, Brazil. In Proceedings of a workshop on neotropical distribution patterns (P.E. Vanzolini \& W.R. Heyer, eds.). Academia Brasileira de Ciências, Rio de Janeiro, p.39-69.

GIULIETTI, A.M., PIRANI, J.R. \& HARLEY, R.M. 1997. Espinhaço Range Region, Eastern Brazil. In Centres of plant diversity. A guide and strategy for their conservation. Vol. 3. The Americas (S.D. Davis, V.H. Heywood, O. Herrera-Macbryde, J. Villa-Lobos \& A.C. Hamilton, eds.). IUCN Publication Unity, Cambridge, p.397-404.

GOLDSBROUGH, C.L., HOCHULI, D.F. \& SHINE, R. 2002. Invertebrate biodiversity under hot rocks: habitat use by the fauna of sandstone outcrops in the Sydney region. Biological Conservation 109:85-93

HAMBLER, D.J. 1964. The vegetation of granitic outcrops in western Nigeria. Journal of Ecology 52:573-594.

HARLEY, R.M. 1995. Introduction. In Flora of the Pico das Almas, Chapada Diamantina, Brazil (B.L. Stannard, ed.). Royal Botanic Gardens, Kew, p.1-42.

HENSEN, I. \& MÜLLER, C. 1997. Experimental and structural investigations of anemochorous dispersal. Plant Ecology 133:169-180.

HOWE, H.F. \& WESTLEY, L.C. 1997. Ecology of pollination and seed dispersal. In Plant ecology (M.J. Crawley, ed.). Blackwell Science, Oxford, p.262-283.

JESUS, E.F.R., FALK, F.H. \& MARQUES, T.M. 1983. Caracterização geográfica e aspectos geológicos da Chapada Diamantina, Bahia. Universidade Federal da Bahia, Salvador.

MADEIRA, J.A. \& FERNANDES, G.W. 1999. Reproductive phenology of sympatric taxa of Chamaecrista (Leguminosae) in Serra do Cipó, Brazil. Journal of Tropical Ecology 15:463-479. 
MATHIAS, A., KISDI, E. \& OLIVIER, I. 2001. Divergent evolution of dispersal in a heterogeneous landscape. Evolution 55:246-259.

MCCORMICK, J.F., ARIEL, E.L. \& SHARITZ, R.R. 1974. Experimental analysis of ecosystems. In Vegetation and environment (B.R. Strain \& W.D. Billings, eds.). Dr. W. Junk, The Hague, p.151-179.

MEDINA, B.M.O., RIBEIRO, K.T. \& SCARANO, F.R. 2006. Plant-plant and plant-topography interactions on a rock outcrop at high altitude in southeastern Brazil. Biotropica 38:27-34.

MEGURO, M., JOLY, C.A. \& BITTENCOURT, M.M. 1977. Stress hídrico e alguns aspectos do comportamento fisiológico em Xerophyta plicata Spreng. - Velloziaceae. Boletim de Botânica da Universidade de São Paulo 5:27-42.

MEIRELLES, S.T. 1996. Estrutura da comunidade e características funcionais dos componentes da vegetação de um afloramento rochoso. Tese de doutorado, Universidade Estadual de Campinas, São Paulo.

MEIRELLES, S.T., MATTOS, E.A. \& SILVA, A.C. 1997. Potential desiccation tolerant vascular plants from Southeastern Brazil. Polish Journal of Environmental Studies 6:17-21.

MONASTERIO, M. \& SARMIENTO, G. 1976. Phenological strategies of plant species in the tropical savannah and the semi-deciduous forest of the Venezuelan Llanos. Journal of Biogeography 3:325-356.

NEWSTROM, L.E., FRANKIE, G.W. \& BAKER, H.G. 1994. A new classification for plant phenology based on flowering patterns in lowland tropical rain forest trees at La Selva, Costa Rica. Biotropica 26:141-159.

NIMER, N. 1989. Climatologia do Brasil. 2a ed. Instituto Brasileiro de Geografia e Estatística. Rio de Janeiro.

PARRINI, R., RAPOSO, M.A., PACHECO, J.F., CARVALHÃES, A.M.P., MELO, T.A., FONSECA, P.S.M. \& MINNS, J.C. 1999. Birds of the Chapada Diamantina, Bahia, Brasil. Cotinga 11:86-95.
POREMBSKI, S. \& BARTHLOTT, W. 1997. Seasonal dynamics of plant diversity on inselbergs in the Ivory Coast (west Africa). Botanica Acta 110:466-472.

POREMBSKI, S., MARTINELLI, G. \& OHLEMÜLLER, R. 1998. Diversity and ecology of saxicolous vegetation mats on inselbergs in the Brazilian atlantic rainforest. Diversity and Distributions 4:107-119.

PRIMACK, R.B. \& MIAO, S.L. 1992. Dispersal can limit local plant distribution. Conservation Biology 6:513-519.

RIBEIRO, K.T. \& MEDINA, B.M.O. 2002. Estrutura, dinâmica e biogeografia das ilhas de vegetação sobre rocha do Planalto do Itatiaia, RJ. Boletim do Parque Nacional do Itatiaia 10:11-82.

SAFFORD, H.D. \& MARTINELLI, G. 2000. Southeast Brazil. In Inselbergs (S. Porembski \& W. Barthlott, eds.). Ecological Studies, v.146. Springer-Verlag, Berlin, p.339-389.

SAZIMA, M. 1978a. Biologia floral de espécies de Velloziaceae na Serra do Cipó, Minas Gerais. Tese de doutorado, Universidade de São Paulo, São Paulo.

SAZIMA, M. 1978b. Polinização por moscas em Bulbophyllum warmingianum Cogn. (Orchidaceae), na Serra do Cipó, Minas Gerais, Brasil. Revista Brasileira de Botânica 1: 133-138.

SHURE, D.J. \& RAGSDALE, L. 1977. Patterns of primary succession on granite outcrop surfaces. Ecology 58:9931006.

STEYERMARK, J.A. 1986. Speciation and endemism in the flora of the venezuelan tepuis. In High altitude tropical biogeography (F. Vuilleumier \& M. Monasterio, eds.). Oxford University Press, New York, p.317-373.

VAN DER PIJL, L. 1982 Principles of dispersal in higher plants. Springer-Verlag, Berlin.

WARE, S. 1990. Adaptation to substrate-and lack of it-in rock outcrop plants: Sedum and Arenaria. American Journal of Botany 77:1095-1100.

WHITTAKER, R.J. 1998. Island biogeography: ecology, evolution, and conservation. Oxford University Press, Oxford. 